\title{
The Effect of Neoadjuvant Chemotherapy on HIF-1a Expression in Cervical Uterine Cancer
}

\author{
Ika Wiraswesty, Supriyadi Hari Respati, Sri Sulistyowati, Heru Priyanto \\ Department of Obstetrics dan Gynecology, Faculty of Medicine, Universitas Sebelas Maret/ \\ Dr. Moewardi Hospital, Surakarta
}

\begin{abstract}
Background: Uterine cervical cancer is one of the main causes of female death related to cancer. Neoadjuvant chemotherapy aims to reduce tumor mass to allow radical surgery. HIF$1 \alpha$ is thought to have a key role in the development of cancer and the main target for chemoprevention.

Objective: This study aims to prove the effect of neoadjuvant chemotherapy on HIF-1a expression in uterine cervical cancer as an assessment parameter for chemotherapy response. Subjects and methods: The study was carried out in the Department of Obstetrics and Gynecology and the Pathology Department of Anatomy Dr. Moewardi - Faculty of Medicine, Sebelas Maret University, Surakarta. Thirty (30) cervical cancer samples that met the inclusion and exclusion criteria were examined for HIF-1a expression before and after giving 3 times neoadjuvan chemotherapy. Examination using immunohistochemical methods. Data analysis using t test.

Results: Mean HIF-1 $\alpha$ expression before administration of neoadjuvant chemotherapy $5.10 \pm$ $1.174 \mathrm{cell} /$ field, after administration of neoadjuvant chemotherapy $4.00 \pm 1.174 \mathrm{cell} /$ field with $\mathrm{p}=0.001$.
\end{abstract}

Conclusion: Neoadjuvant chemotherapy has an effect on reducing HIF-1a expression in uterine cervical cancer.

Keywords: neoadjuvant chemotherapy, HIF-1a, uterine cervical cancer

Correspondence:

Sri Sulistyowati. Department of Obstetrics and Gynecology, Faculty of Medicine, Universitas Sebelas Maret. Mobile: o8122968215. email: elis_spog@yahoo.co.id

\begin{abstract}
BACKGROUND
$\overline{\text { Cervical cancer of the uterus is the primary }}$ malignancy of the cervix which is in the portion and cervical canal (Andrijono, 2016). According to WHO, cervical cancer ranks second after breast cancer. Around the world more than 200 thousand people die each year from cervical cancer (World Health Organization, 2014). In Central Java the incidence of cervical cancer is more than 2000 cases and in Dr. Moewardi Hospital Surakarta in 2013 there were more than 1700 cases of cervical cancer patients (Wardani, 2014).
\end{abstract}

Neoadjuvant chemotherapy aims to allow surgical action on cervical cancer which has a major obstacle to primary lesions, chemotherapy is expected to reduce tumor mass so as to allow radical surgery (Berman, 2015). The success of neoadjuvant chemotherapy is influenced by the type of chemotherapy given and gives a better response if given in combination with minimal risk of resistance (Andrijono, 2016). Cisplatin and Paclitaxel chemotherapy regimens are a combination of drugs that have a rapid, free-survival therapy response and can improve quality of life. The combination of Carboplatin and 
Paclitaxel is easy to supply, administration and tolerance is also the first choice in chemotherapy (Koh, 2016). The chemotherapy combination is more sensitive in cervical cancer patients with squamous cell types than other types such as adenocarcinoma and clear cell (Chen et al., 2017).

Hypoxia inducible factors- $1 \alpha$ (HIF-1 $\alpha$ ) is a transcription factor that responds to tissue hypoxia that occurs in the stages of carcinogenesis. Cells that experience hypoxia stimulate the secretion of HIF-1a in cervical cancer, then HIF-1a stimulates the expression of various genes that are important in the development of cancer.

This study aims to determine the effect of neoadjuvant chemotherapy on the expression of HIF-1a in uterine cervical cancer.

\footnotetext{
SUBJECTS AND METHOD

This study is a prospective cohort study conducted on early stage cervical cancer patients given Paclitaxel-Carboplatin neoadjuvant chemotherapy 3 times. The study was conducted in the Department of Obstetrics and Gynecology and the Pathology Section of the Anatomy of the Dr. Moewardi - Faculty of Medicine, Sebelas Maret University Surakarta in November 2017 April 2018. The research subjects were cervical cancer patients who came to the Gynecology Oncology Clinic, as well as in the Nursing Room of Dr. Hospital. Moewardi, Surakarta. The inclusion criteria were early stage IB2 and IIA2 cervical cancer patients with a bulky tumor (diameter of cervical lesion $>4 \mathrm{~cm}$ ) and had never received treatment. The exclusion criteria are "there are medical disorders/ systemic diseases that are dangerous such as hypertension, thromboembolism and heart disease or contra indications of chemotherapy and surgery" and "there are
}

tumors/malignancies in addition to uterine cervical cancer" (Stefani, 2016).

The dose of Paclitaxel used is $175 \mathrm{mg} /$ m2. The dose of Carboplatin used is 5 (AUC) $\mathrm{x}(25+$ GFR $)$. Chemotherapy is given 3 times at intervals between chemotherapy for 3 weeks.

Examination of HIF-1 1 a expression in cervical cancer before and after receiving neoadjuvant chemotherapy employed HIF$1 \alpha$ antibody reagent from Abcam Cambridge Science Park, UK in 2012. Painting was done using Avidin Biotin Complex from Biocare Medical, LLC, Concord, USA. The unit of measurement is the sum of the number of colored field perceptions and the percentage of their intensity.

This study employed the immunohistochemistry method. Evaluating of the quality (intensity) of immunoreaction and combining the examination of the intensity score with the quantity (fraction) of cells stained to produce a semiquantitative scoring system were done. The system is intended to reduce the subjectivity of examiners.

This study was conducted by two examiners by assessing how to read according to Birner et al (2000) from all fields of view using a Olympus Cx 21 microscope with a 400x microscope (10x ocular lens, 40x objective lens). First, the reagent area is seen in color, if the total area is $11-50 \%$, the score is $2,51-80 \%$ is given a score of 3 , $>81 \%$ is given a score 4 . Then the intensity of the color of the reagent is assessed. If the weak intensity is given a score of 1 , the intensity is being given a score of 2, the intensity is given a score of 3 . Then both the results of the area/percentage and intensity are added together. Negative expressions are said if $<10 \%$ are positive cells, value 3 for weak expressions, 4-5 values for moderate expressions, and values 6-7 for strong expressions (Birner et al., 2000). 
The research ethics include informed consent, anonymity, confidentiality and ethical conduct. Ethical Feasibility of this research was carried out in dr. Moewardi hospital, Surakarta, with no. Ethical feasibility: 708 / IX / HREC / 2018.

\section{RESULTS}

The characteristics of the research subjects in table 1 show that the majority of samples were $40-60$ years old $(73.3 \%)$ and at least $<40$ years (16.7\%); Most of them are elementary school graduates of 15 samples (50.0\%) and at least 1 sample diploma (3.33\%); Parity $0-2$ is the highest 19 samples (63.33\%), the lowest parity> 4 is 1 sample (3.33\%); Most stage IIA2 is 27 samples (90.0\%), at least IB2 is 3 samples (10.0\%). The highest histological sample of squamous cell carcinoma was 25 samples (83.33\%) and the lowest was 5 samples (16.67\%) histology in addition to squamous cell carcinoma. This figure shows the histopathological type of squamous cell carcinoma more dominant than other cell types such as adenocarcinoma and clear cell.

Table 1. Sample Characteristic

\begin{tabular}{lll}
\hline Charactersitics & n & \% \\
\hline Age & & \\
\hline < 40 years old & 5 & 16.7 \\
40-60 years old & 22 & 73.3 \\
> 60 years old & 3 & 10.0 \\
Education & & \\
Elementary school & 15 & 50.0 \\
Junior high school & 4 & 13.3 \\
Senior high school & 8 & 26.7 \\
Diploma & 1 & 3.3 \\
Bachelor & 2 & 6.7 \\
Parity & & \\
O - 2 & 19 & 63.33 \\
3 to 4 & 10 & 33.33 \\
> 4 & 1 & 3.33 \\
Stage of cancer & & \\
I B2 & 3 & 10.0 \\
II A2 & 27 & 90.0 \\
Histology & & \\
KSS & 25 & 83.33 \\
Non KSS & 5 & 16.67 \\
\hline
\end{tabular}

HIF-1 $\alpha$ expression in early cervical uterine cancer patients before and after neoadjuvant chemotherapy paclitaxelcarboplatin was described in graph 1 where HIF-1 $\alpha$ expression was lower after neoadjuvant chemotherapy.

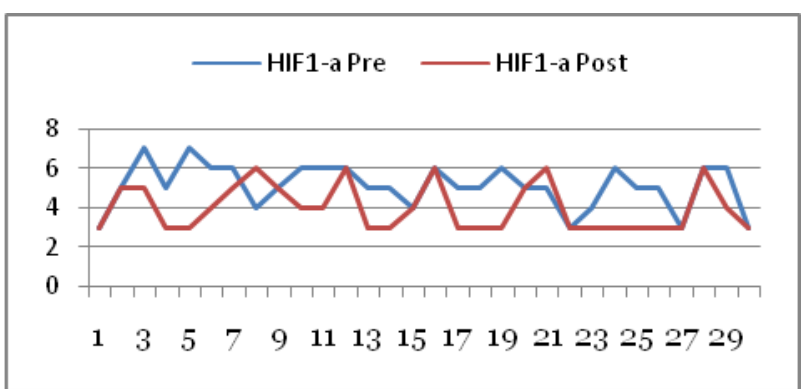

Figure 1. Expression of HIF--1 $\alpha$ Pre and Post Chemotherapy Neoadjuvan Paclitaxel - Carboplatin

In the normality test of the expression of HIF-1 $\alpha$ by using the normal distribution test (Shapiro-Wilk) and after administration of neoadjuvant chemotherapy with the results of the normality test described that the data was not normally distributed. The value of $p=0.004$ for the results before chemotherapy and $\mathrm{p}<0.001$ for the results after chemotherapy.

The mean of HIF $1 \alpha$ tissue expression before the administration of neoadjuvant chemotherapy was higher $($ mean $=5.10$; $\mathrm{SD}=1.12)$ cells compared to after neoadjuvant chemotherapy $($ mean $=4.00 ; \mathrm{SD}=1.17)$ cells with $\mathrm{p}=0.001$.

Table 3. Mean difference test for HIF1a expression in tissues before and after administration of neoadjuvant chemotherapy

\begin{tabular}{|c|c|c|c|}
\hline Group & $\mathbf{N}$ & $\begin{array}{c}\text { Expression } \\
\text { average } \\
\text { HIF-1a } \\
\text { (cells) }\end{array}$ & $\mathbf{p}$ \\
\hline $\begin{array}{l}\text { Before } \\
\text { chemotherapy }\end{array}$ & 30 & $5.10 \pm 1.13$ & 0.001 \\
\hline $\begin{array}{l}\text { After } \\
\text { chemotherapy }\end{array}$ & 30 & $4.00 \pm 1.17$ & \\
\hline
\end{tabular}

The expression of HIF-1 $\alpha$ in the cytoplasm provided microscopic dark 
brown color images by using immunohistochemical analysis.

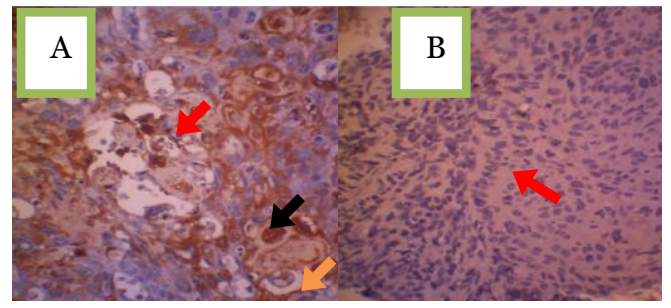

Figure 2. HIF-1a Expression

Information :

A. Before conducting neoadjuvant chemotherapy. The black arrow showed a picture of strong expression on the core with dark brown color. The red arrow showed strong expression on the cytoplasm with dark brown color. Yellow arrows indicated cells that did not express HIF-1a, a "hello" picture. B. After administration of neoadjuvant chemotherapy which shown by the red arrow was the expression of HIF-1a in the cytoplasm after the administration of light brown color neoadjuvant chemotherapy. Brownish color was a reaction between staining with 1-a HIF antibody and hematoxylin eosin. Examination using $\mathrm{Cx} 21$ Olympus microscope with $400 \mathrm{x}$ magnification.

\section{DISCUSSIONS}

The expression of HIF-1 $\alpha$ in uterine cervical cancer has been observed in 30 study samples before and after neoadjuvant chemotherapy according to immunohistochemical staining based on an assessment according to Birner et al. The analysis showed a significant decrease in the rate of HIF-1a expression in uterine cervical cancer after administration of neoadjuvant chemotherapy $(\mathrm{p}=0.001)$.

In cervical cancer, the expression of HIF-1a was increased which played an important role in the effects of metabolism, angiogenesis, metastasis, and inflammation in cervical cancer cells. Expression of HIF-
$1 \alpha$ in solid tumors has been detected in hypoxic cell perinecrotic regions (Melillo, 2014). Angiogenesis in cervical cancer has been shown to be induced by HIF-1a through activation of HIF-1 and VEGF target gene expression. In hypoxic conditions, there was aggressiveness in tumor growth. Activation of the HIF-1a pathway in cancer tissue specimens has been discussed in several immunohistochemical studies. In 2012, a study by Dos Santos et al regarding the expression of HIF-1a in squamous cell carcinoma in the oral cavity showed that strong HIF-1a expression was associated with a high rate of disease recurrence. Tumors with high HIF-1a expression activate transcription of genes related to angiogenesis, including VEGF, so that they can be predictors of the success rates of radiotherapy or chemotherapy.

The effect of neoadjuvant chemotherapy on high expression of HIF-1a in cervical cancer, chemotherapy caused more death of neoplastic cells, which can reduce the size of cervical lesions and improve vascularization in cancer cells because tumors have irregular vascularization and O2 cellular imbalance occurred, so that after administration of neoadjuvant chemotherapy, it resulted in high oxygenation of cervical cancer tissue and indirectly decreased the HIF-1a expression (dos santos et al., 2012).

Paclitaxel and carboplatin were used in this study because in general, tumors that experienced hypoxia were resistant to conventional radiotherapy and chemotherapy with high levels of aggressiveness. Oxygen homeostasis in cells and hypoxic stress occurred mostly through the HIF pathway. However, dysregulation on the HIF pathway was related to poor outcomes if it used conventional therapy. This was because the hypoxic cell state was a reaction of a cancer cell to maintain the 
survival of cancer cells, became aggressive, and protection against anti-cancer therapy. Currently, therapy was focused on reactive oxygen substances that can increase the death of DNA in damaged cells. Therefore, the target of therapy was on the HIF pathway with therapeutic strategies on hypoxia and angiogenic tumors by using combination chemotherapy of paclitaxel and carboplatin to inhibit HIF-1a which has been shown to be clinically beneficial and resulting in a decrease in HIF-1a expression (Poon, Harris and Ashcroft, 2009).

The expression of HIF-1a in cervical cancer tissue has decreased significantly after administration of neoadjuvant chemotherapy in line with research by Birner et al. (2000) where hypoxia increased radiation resistance and depend on HIF-1a by increasing VEGF expression and inhibiting p53 expression.

Previous studies of breast cancer showed that positive expression of HIF-1a in neoadjuvant chemotherapy where the value of HIF-1a expression in breast cancer tissue was lower after chemotherapy than before chemotherapy with (Ruihua, Yongqiang and Zongzhu, 2017). Based on this study and supported by previous studies, it showed that the level of HIF-1a protein can be used as a prognostic marker in various cancers.

In uterine cervical cancer patients with high HIF-1a expression which has a poor prognosis, with a $73 \%$ survival rate, and with low HIF-1a expression, it has 93\% survival rate. These data indicated that HIF-1a was needed at the initiation phase of cancer development and played an important role in the development and ability of metastasis(Onnis, Rapisarda and Melillo, 2009).

Based on the results of this study, it can be concluded that the administration of neoadjuvant chemotherapy has an effect on reducing the expression of HIF-1a in uterine cervical cancer patients.

\section{REFERENCES}

Andrijono (2016). Kanker Serviks. Bab V. Edisi-5. Badan Penerbit Fakultas Kedokteran Universitas Indonesia, jakarta. 95-119.

Berman N (2015), Association of Reproductive Health Profesional. (2015). HPV and Cervical Cancer. ARHP clinical proceeding.

Birner P, Schindl M, Obermair A, Plank C, Breitenecker G, Oberhuber G (2000). Overexpression of Hypoxia-inducible Factor 1 a Is a Marker for an Unfavorable Prognosis in Early-Stage Invasive Cervical Cancer Advances in Brief Prognosis in Early-Stage Invasive Cervical Cancer Res. 60 (17):4693-6.

Chen P, Jiao L, Wang D (2017). Squamous cell carcinoma antigen expression in tumor cells is associated with the chemosensitivity and survival of patients with cervical cancer receiving docetaxel-carboplatin-based neoadjuvant chemotherapy,Oncol Lett. 13(3): 1235-1241. doi: 10.3892/ol.2017.5560.

dos Santos M, Mercante AM, Louro ID, et al. (2012). HIF1-alpha expression predicts survival of patients with squamous cell carcinoma of the oral cavity. PLoS One. 2012;7(9):e45228. doi: 10.1371/journal.pone.0045228

Hyngstrom JR, Posner MC (2010). Neoadjuvant strategies for the treatment of locally advanced esophageal cancer. J Surg Oncol. 101(4):299-304. doi: $10.1002 /$ jso.21479.

Koh WJ. (2016). National Comprehensive Cancer Network (NCCN) Cervical Cancer. Version I.2016. NCCN Clinical Practice Guidelines in Oncology. 
Indonesian Journal of Medicine (2018), 3(2): 119-124

https://doi.org/10.26911/theijmed.2018.03.02.08

Onnis B, Rapisarda A and Melillo G. (2009). Development of HIF-1 inhibitors for cancer therapy. $\mathrm{J}$ Cell $\mathrm{Mol}$ Med. 13(9A): 2780-2786. doi: 10.1111/j.1582-4934.2009.00876.x.

Poon E, Harris AL and Ashcroft M. (2009). Targeting the hypoxia-inducible factor (HIF) pathway in cancer.Expert Rev Mol Med. 11:e26. doi: 10.1017/S1462399409001173.

Ruihua T, Yongqiang L and Zongzhu Z. (2017). The study of correlation between neoadjuvant chemotherapy and the expression of VEGF, HIF-1 $\alpha$ and MVD in breast cancer.Biomedical Research. Special Issue: S537-S541.

Stefani L, Galanti G, Klika R (2017). Clinical
Implementation of Exercise Guidelines for Cancer Patiens: Adaptation of ACSM's Guidelines to the Italian Model. J. Funct. Morphol. Kinesiol; 2(4):2017

Wardani EK (2014).Respon Fisik dan Psikologi Wanita dengan Kanker Serviks yang Telah Mendapat Kemoterapi di RSUD Dr. Moewardi Surakarta. [Skripsi] Surakarta: FK UNS.

World Health Organisation. (2014). Comprehensive Cervical Cancer Control. A guide to essential practice - 2nd edition. http://www.who.int/reproductivehealth/publications/cancers/cervical-cancer-guide/en/ 